by Maria Bianca Cital ${ }^{\text {, Philip L. Gibbard }}{ }^{2}$, Martin J. Head ${ }^{3}$, and the ICS Subcommission on Quaternary Stratigraphy ${ }^{\dagger}$

\title{
Formal ratification of the GSSP for the base of the Calabrian Stage (second stage of the Pleistocene Series, Quaternary System)
}

1 Dipartimento di Scienze della Terra ‘Ardito Desio', Universita' degli Studi di Milano, via Mangiagalli, 34, 20133 Milano, Italy

2 Cambridge Quaternary, Department of Geography, University of Cambridge, Downing Street, Cambridge CB2 3EN, U.K.

E-mail:plg1@cam.ac.uk

3 Department of Earth Sciences, Brock University, 500 Glenridge Avenue, St. Catharines, Ontario L2S 3A1, Canada. E-mail: mjhead@brocku.ca

The Calabrian Stage is now formally defined by the Global Boundary Stratotype Section and Point (GSSP) at Vrica, Calabria, Italy. This GSSP had previously defined the base of the Pleistocene Series. The Calabrian becomes the second stage of the Pleistocene Series and Quaternary System, following the Gelasian. The GSSP occurs at the base of the marine claystone conformably overlying sapropelic bed 'e' within Segment B in the Vrica section. This lithological level represents the primary marker for the recognition of the boundary, and is assigned an astronomical age of 1.80 Ma on the basis of sapropel calibration. It coincides with the transition from Marine Isotope Stage 65 to 64, and the underlying sapropel bed ' $e$ ' is assigned to the Mediterranean Precession-Related Sapropel layer 176. Secondary markers include calcareous plankton bioevents of widely distributed taxa. The boundary falls between the highest occurrence of Discoaster brouweri (below) and the lowest common occurrence of left-coiling Neogloboquadrina pachyderma (above), and below the lowest occurrences of medium-sized Gephyrocapsa (including G. oceanica) and Globigerinoides tenellus. The top of the Olduvai Subchron is identified c. 8 m above the GSSP. Ratification of the Calabrian Stage effectively completes the Lower Pleistocene Subseries.

\section{Introduction}

On 5 December 2011, the Executive Committee of the International Union of Geological Sciences (IUGS) ratified a request by the International Commission on Stratigraphy (ICS) that the Global Boundary Stratotype Section and Point (GSSP) at Vrica, Calabria, Italy (Fig. 1) be used to define the base of the Calabrian Stage of the Pleistocene Series and Quaternary System. The Vrica GSSP had previously defined the base of the Pleistocene and Quaternary before these datum points were lowered in 2009 to the Monte San Nicola GSSP in Sicily, Italy, which also defines the base of the Gelasian Stage (Gibbard and Head, 2010; Gibbard et al., 2010). The proposal had been submitted to the ICS by the Subcommission on Quaternary Stratigraphy (Table 1) on 29 November 2010, and was approved by the ICS on 2 May 2011 with an 85\% majority (15 'yes', one 'no', one 'abstain', one 'non-response'). Ratification by the IUGS makes the Calabrian the second stage of the Pleistocene Series, immediately following the Gelasian as the lowest stage (Fig. 2). It is emphasised that the ratified proposal does not define a new GSSP, but merely names the stage that the GSSP now defines.

The Calabrian Stage has been in existence for just over a century (Gignoux, 1910, 1913) and is well rooted in the literature, although its use beyond the Mediterranean domain declined after 1984 when the ICS approved the base Pleistocene GSSP in the Vrica section (Aguirre and Pasini, 1985) with a currently assigned age of 1.80 Ma. Nonetheless, its use has increased internationally in recent years, and its definition has been clarified together with calls for it to be accepted as a formal stage within the international geological time scale (Cita et al., 2006, 2008). In particular, now that the Pleistocene has been expanded to incorporate the Gelasian Stage, the Calabrian offers a practical means of subdividing this lower part of the Pleistocene. Indeed, these two stages together will comprise the Lower Pleistocene Subseries (Early Pleistocene Subepoch).

\section{Background and Rationale}

It is well known that most Quaternary deposits exposed on land are non-marine in nature, discontinuous in space and time, poorly fossiliferous, and often difficult to date. The Mediterranean is a small ocean basin with a complicated geodynamic history and active

${ }^{\dagger}$ B. Alloway, A. G. Beu, M. Coltorti, P. L. Gibbard (Past-Chair), V. M. Hall, M. J. Head (Chair), Liu Jiaqi, K. L. Knudsen, T. van Kolfschoten (Past-Secretary), T. Litt, L. Marks, J. McManus (Past-Vice-Chair), J. A. Piotrowski, B. Pillans (Vice-Chair), M. Räsänen, S.O. Rasmussen, D.-D. Rousseau, J.-P. Suc, A. S. Tesakov, C. Turner, M. J. C. Walker, J. Zalasiewicz (Secretary), and C. Zazo (Table 1). 


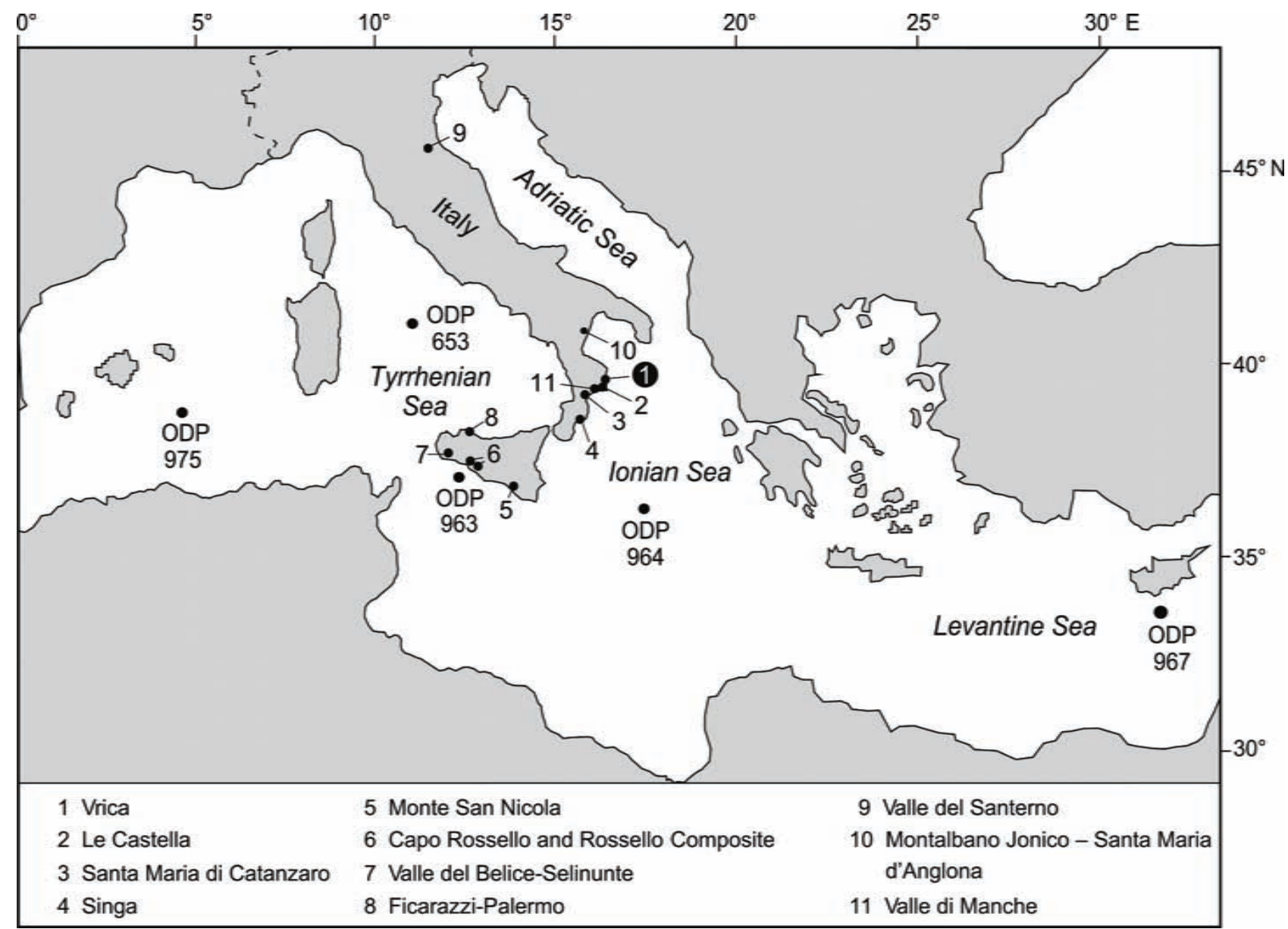

Figure 1. Location of prominent onshore sections and ODP sites mentioned in the text.

orogenic belts surrounding and crossing it. As a consequence, some coastal areas of Sicily and southern Italy expose relatively deepwater marine sediments that have been uplifted through the last three million years or so. This presents a unique opportunity to decipher the stratigraphy with an array of modern techniques, and compare this integrated stratigraphy with the deep-sea record investigated by scientific drilling in the Mediterranean (Fig. 1) and throughout the world's oceans.

When Selli et al. (1977) proposed the Vrica section as a potential Neogene/Quaternary boundary stratotype following the protocol of the International Stratigraphic Guide (Hedberg, 1976), they were also fullfilling the recommendation of the 1948 (London) International Geological Congress that the Neogene/Quaternary boundary be defined in a marine section in Italy in correspondence with the first immigration of 'northern guests' in the Mediterranean basin.

But this decision prompted a strong and persistent reaction among the large community of continental Quaternarists, and other stratigraphers, because evidence for the initiation of a marked cooling in the Northern Hemisphere was incontrovertably older than the 1.80 Ma age assigned to the Vrica GSSP (Figs. 3, 4; Head et al., 2008a; Gibbard and Head, 2010). Moreover, the first appearance of northern guests in the Mediterranean was considered irrelevant in a global context.

It follows from the above that the Quaternary Subcommission of the ICS, which consists largely of non-marine specialists, promptly favoured the adoption of the Gelasian GSSP to define the base Pleistocene and base Quaternary, although the Gelasian had been proposed as the youngest stage of the Pliocene as recently as 1998 (Rio et al., 1998), a few years after the first description of the Monte San Nicola section by Channell et al. (1992).

Following the IUGS ratification (on 29 April, 2009) of a coincident base for the Quaternary System, Pleistocene Series, and Gelasian Stage, it became appropriate to address the issue of the Calabrian Stage. Full details of the Calabrian Stage GSSP are given in Cita et al. (2008), and additional information is provided by the Istituto Superiore per la Protezione e la Ricerca Ambientale (ISPRA) website at: http://sgi2.isprambiente.it/geositiweb/gssp/lavrica.htm. Essential information on the Calabrian Stage now follows.

\section{Essentials of the Calabrian Stage}

The Calabrian is the second stage of the Pleistocene, following the Gelasian. Its upper limit, while currently undefined, will be established by the base of the stage representing the Middle Pleistocene Subseries, the recommended primary guide for which is the Matuyama/Brunhes polarity chron boundary (Head et al., 2008b) as this will facilitate marine/non-marine correlations. Several potential GGSPs for the Lower/Middle Pleistocene boundary (e.g., Head et al., 2008b; Maiorano et al., 2010) are under consideration. While treating the Lower, Middle, and Upper Pleistocene Subseries as formal subdivisions following current practice (e.g., Gibbard et al., 2010), we do note that these terms have yet to be officially sanctioned by the ICS/IUGS.

The base Calabrian GSSP is located in the Vrica section, province 
Table 1 ICS Subcommission on Quaternary Stratigraphy (2011)

\begin{tabular}{|c|c|}
\hline B. Alloway & $\begin{array}{l}\text { School of Geography and Earth Sciences, Victoria University of Wellington, } \\
\text { PO Box } 600 \text {, Wellington, New Zealand }\end{array}$ \\
\hline A. G. Beu & $\begin{array}{l}\text { School of Geography and Earth Sciences, Victoria University of Wellington, } \\
\text { PO Box } 600 \text {, Wellington, New Zealand }\end{array}$ \\
\hline M. Coltorti & Dipartimento di Scienze della Terra, University of Siena, Italy \\
\hline P. L. Gibbard (Chair) & Department of Geography, University of Cambridge, UK \\
\hline V. M. Hall & School of Archaeology and Palaeoecology, Queen's University, Belfast, UK \\
\hline M. J. Head & Department of Earth Sciences, Brock University, Canada \\
\hline Liu Jiaqi & $\begin{array}{l}\text { Institute of Geology and Geophysics, Chinese Academy of Sciences, Beijing, } \\
\text { China }\end{array}$ \\
\hline K. L. Knudsen & Department of Earth Sciences, University of Aarhus, Denmark \\
\hline $\begin{array}{l}\text { T. van Kolfschoten } \\
\text { (Secretary) }\end{array}$ & Faculty of Archaeology, Leiden University, The Netherlands \\
\hline T. Litt & Institute of Paleontology, University of Bonn, Germany \\
\hline L. Marks & Polish Geological Institute, Warsaw, Poland \\
\hline $\begin{array}{l}\text { J. McManus } \\
\text { (Vice-Chair) }\end{array}$ & Lamont-Doherty Earth Observatory, Columbia University, USA \\
\hline J. A. Piotrowski & $\begin{array}{l}\text { Department of Earth Sciences, University of Aarhus, Denmark; and } \\
\text { Department of Geography, University of Sheffield, UK. }\end{array}$ \\
\hline B. Pillans & $\begin{array}{l}\text { Research School of Earth Sciences, The Australian National University, } \\
\text { Canberra, Australia }\end{array}$ \\
\hline M. Räsänen & Department of Geography and Geology, University of Turku, Finland \\
\hline S. O. Rasmussen & $\begin{array}{l}\text { Centre for Ice and Climate, Niels Bohr Institute, University of Copenhagen, } \\
\text { Denmark }\end{array}$ \\
\hline D.-D. Rousseau & $\begin{array}{l}\text { Ecole Normale Supérieure, Laboratoire de Météorologie Dynamique and } \\
\text { CERES-ERTI, Paris, France }\end{array}$ \\
\hline J.-P. Suc & $\begin{array}{l}\text { Institut des Sciences de la Terre Paris, Laboratoire Evolution et Modélisation } \\
\text { des Bassins Sédimentaires, Université Pierre et Marie Curie, Paris, France }\end{array}$ \\
\hline A. S. Tesakov & Geological Institute, Russian Academy of Sciences, Moscow, Russia \\
\hline C. Turner & Department of Geography, University of Cambridge, UK \\
\hline M. J. C. Walker & $\begin{array}{l}\text { Department of Archaeology and Anthropology, University of Wales, Lampeter, } \\
\text { Wales, UK; and Institute of Geography and Earth Sciences, Aberystwyth } \\
\text { University, Wales, UK }\end{array}$ \\
\hline J. Zalasiewicz & Department of Geology, University of Leicester, UK \\
\hline C. Zazo & $\begin{array}{l}\text { Departamento de Geología, Museo Nacional de Ciencias Naturales (CSIC), } \\
\text { Madrid, Spain }\end{array}$ \\
\hline
\end{tabular}

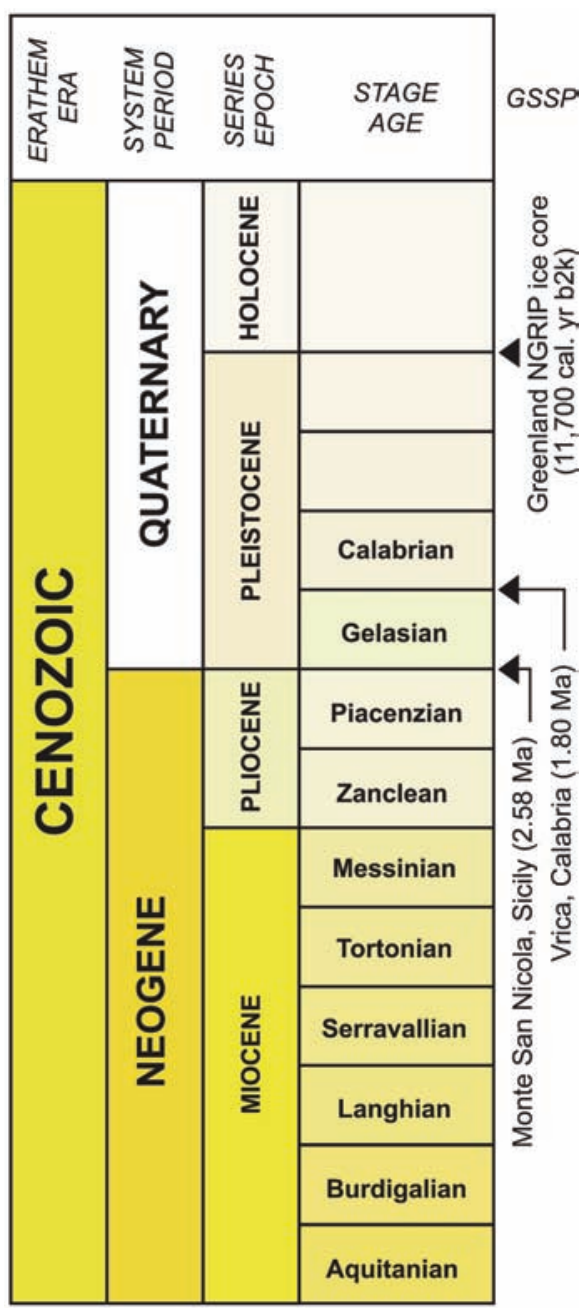

Figure 2. Current IUGS-sanctioned time scale for the Cenozoic, showing GSSPs for the Quaternary and including the newlyratified Calabrian Stage (Modified from Gibbard and Head, 2010, fig. 1). of Crotone, Calabria (latitude $39^{\circ} 02^{\prime} 18.61^{\prime \prime} \mathrm{N}$, longitude $17^{\circ} 08^{\prime} 05.79^{\prime \prime}$ E), some $4 \mathrm{~km}$ south of the town. The GSSP is defined at the base of the marl bed immediately overlying sapropel 'e', as identified in a succession of silty marls, dark grey or blue-grey in colour, that outcrop in badlands subject to regolith creep (Fig. 4). Interbedded with the marls are sapropelic layers, grey-pink in colour and finely laminated, indicative of poorly oxygenated conditions. The marls are richly fossiliferous, especially in calcareous nannoplankton and planktonic foraminifers but also in ostracods, benthic foraminifers (Figs. 5 and 6), and palynomorphs. Sedimentation rates are high in the Crotone series, ranging from $c .45 \mathrm{~cm} \mathrm{ka}^{-1}$ near the base, to $c .29 \mathrm{~cm} \mathrm{ka}^{-1}$ at around 1.8 Ma (Suc et al., 2010).

Magnetostratigraphic investigations by various groups of specialists have differed in identifying the top of the Olduvai Subchron (Fig. 5), these discrepancies being a result of complex early and late diagenetic overprinting. It is generally accepted, however, that the upper boundary occurs c. $8 \mathrm{~m}$ above the GSSP (Hilgen, 1990; Zijderveld et al., 1991; Roberts et al., 2010), but that the Vrica section should not be relied upon for further refinement of its age (Roberts et al., 2010).

Strontium isotope studies (Barbieri et al., 1998) support the age determinations based on biochronology and magnetostratigraphy.

The badlands geomorphology, in which the stratotype occurs, prevents the construction of permanent markers for the GSSP. However, this has not obstructed the numerous international groups that have measured and sampled the section following its original

Figure 4. The Vrica section and surrounding area. (a) Panorama of the three Vrica segments, A, B, and C, and the nearby Santa Lucia section. Correlation is precise between Vrica $A$ and Vrica $B$ as they are on the same plane, but more speculative between both Vrica $B$ and Vrica C, and Vrica C and Santa Lucia. Photograph courtesy of J.-P. Suc. (b) Lithological sequence of Segment B in the Vrica stratotype section showing the prominent sapropel layers: $b, c, d, e, f$, and $h$. The GSSP of the Calabrian Stage is fixed at the top of layer ' $e$ '. (c) detail of Segment B showing a person (indicated by arrow) standing in front of layer ' $e$ '. Photographs (b) and (c) taken in 2000, courtesy of Ilka von Dalwigk and Luca Capraro. 


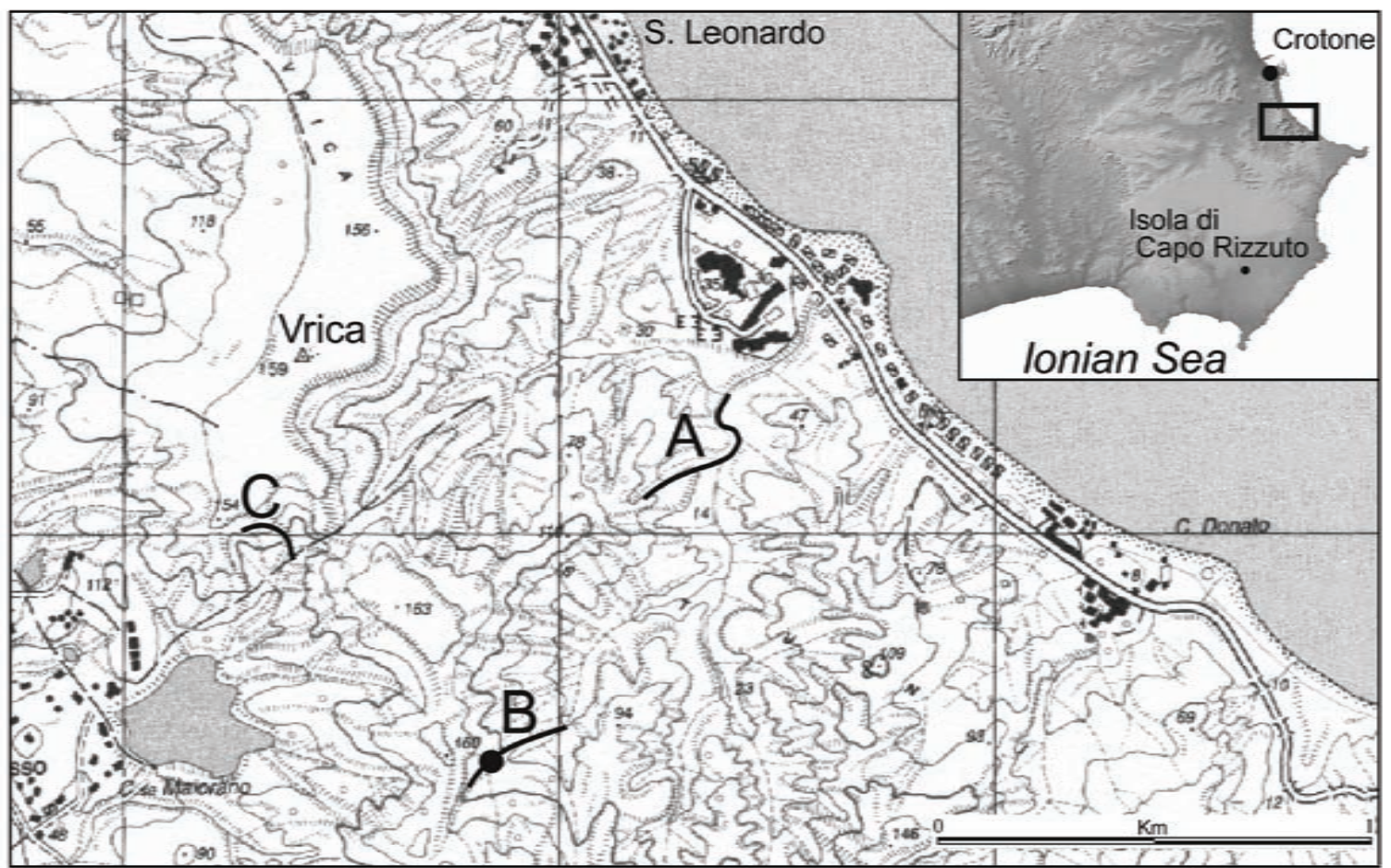

Figure 3. Location of the Vrica boundary stratotype section. A, B, and C are the component segments of the section. The dot on segment $B$ represents the position of the Calabrian GSSP. After Cita et al. (2008, fig. 2a).

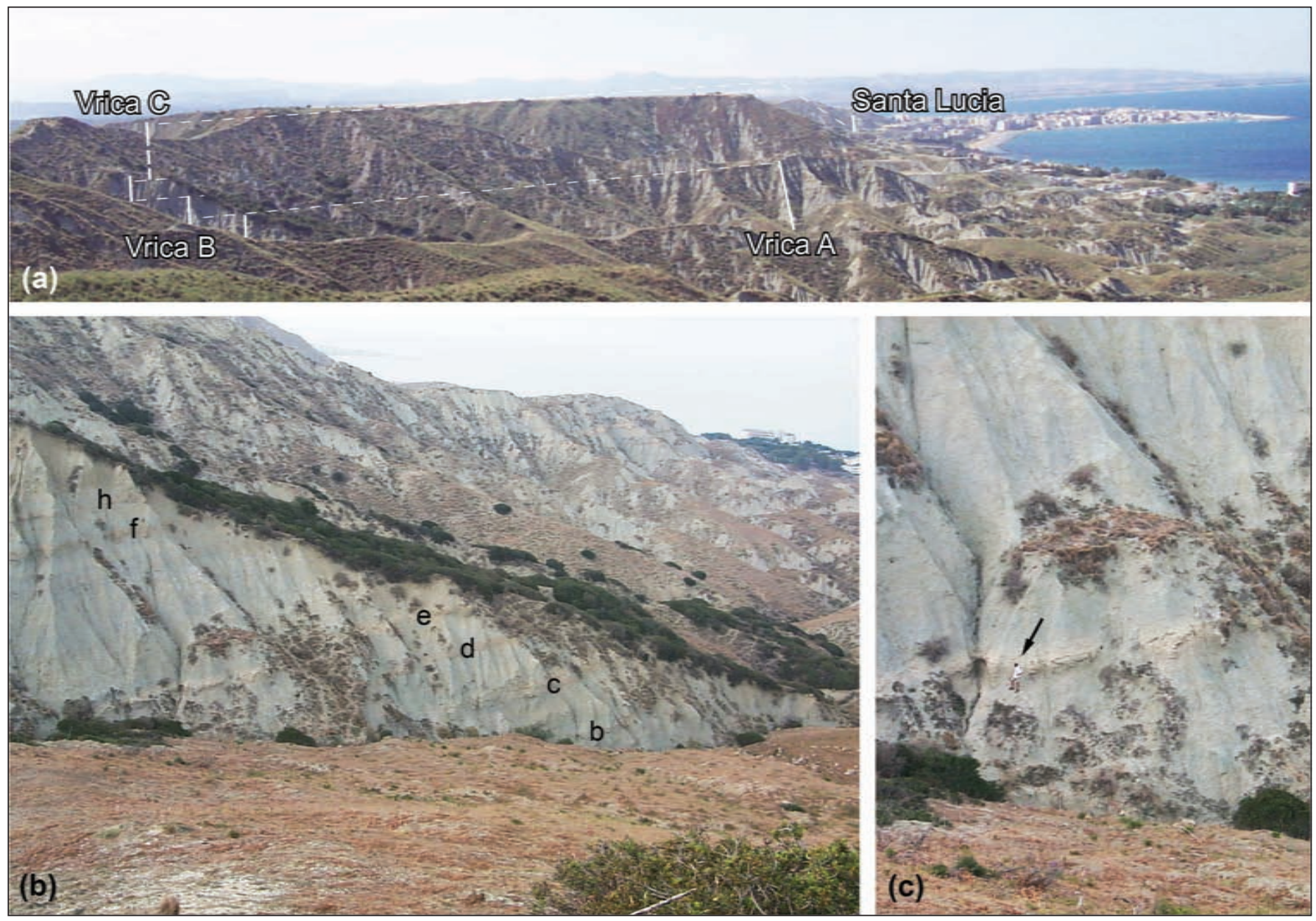

Figure 4. Caption on opposite page. 


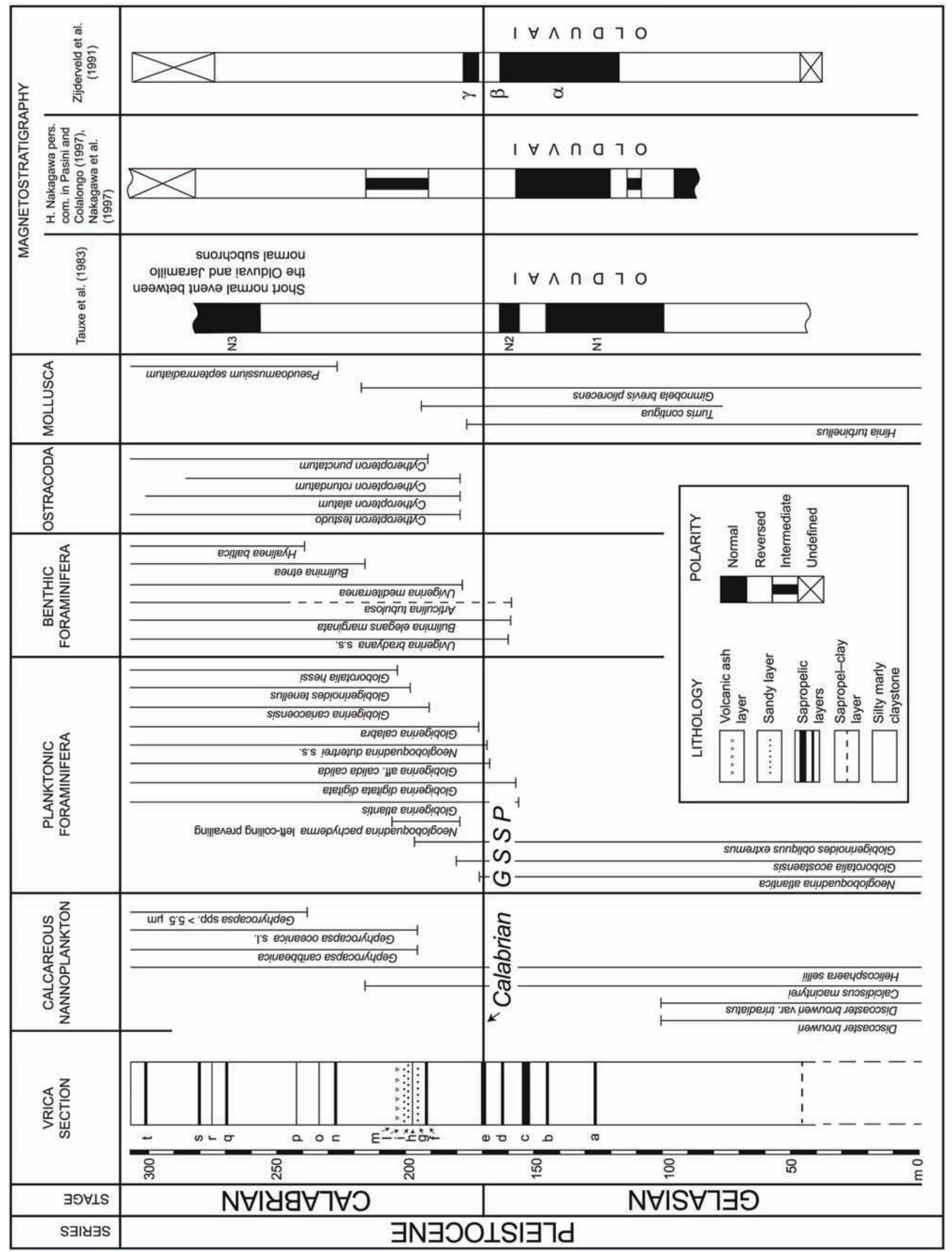

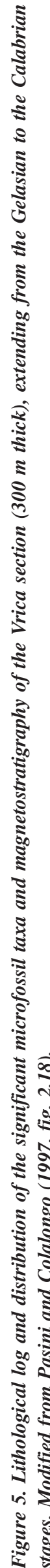




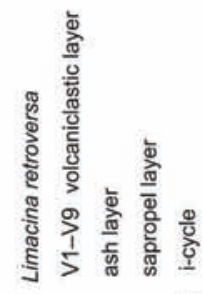

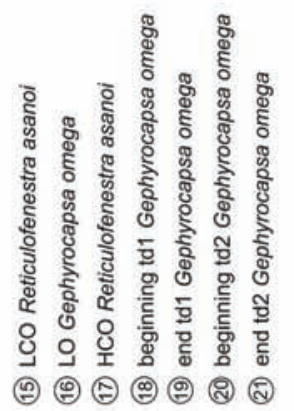

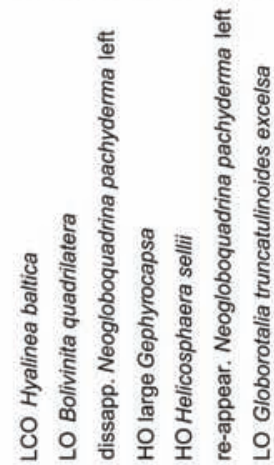

回 回

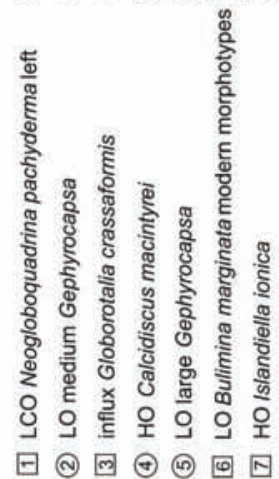

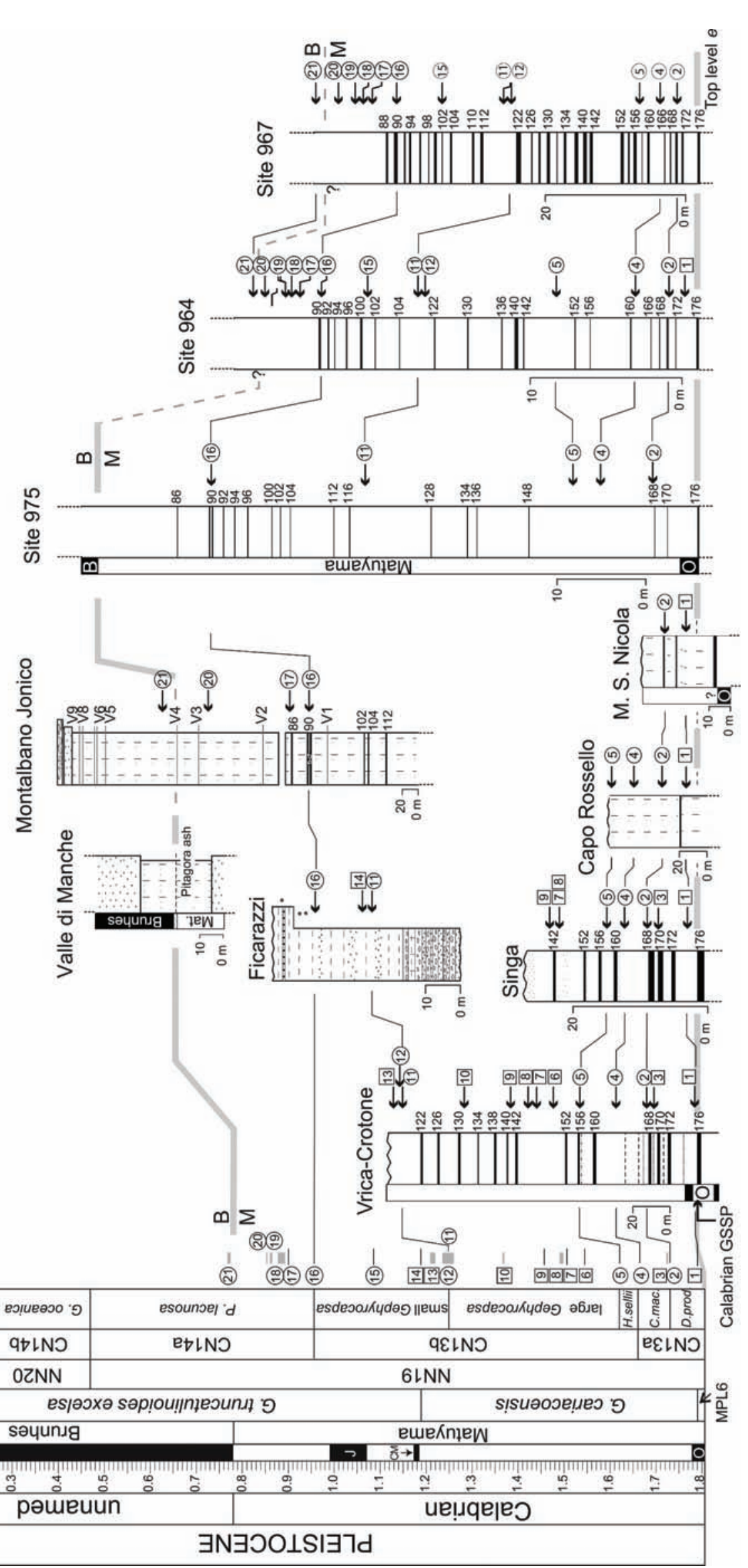

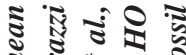

를

농ำ

รัง ฮั

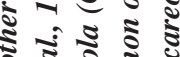
จ. క เั ใิ ขร 촌 \& है 농 ०ूे

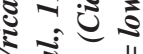
ะ ะ. ำ s 혼 온 욜 旅

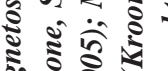
요요 ป ป⿱艹

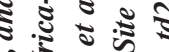
ลิ क्षे

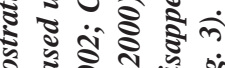

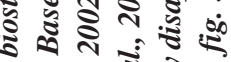

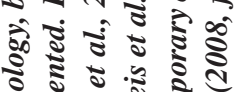

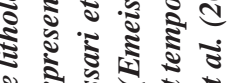

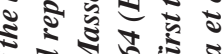

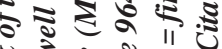

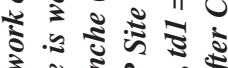
ริ

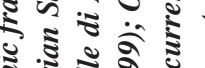
๘ U ะ จิ ริ एक เै.

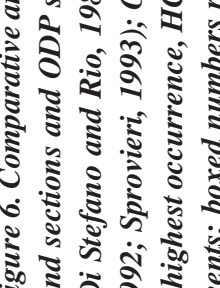

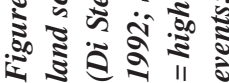




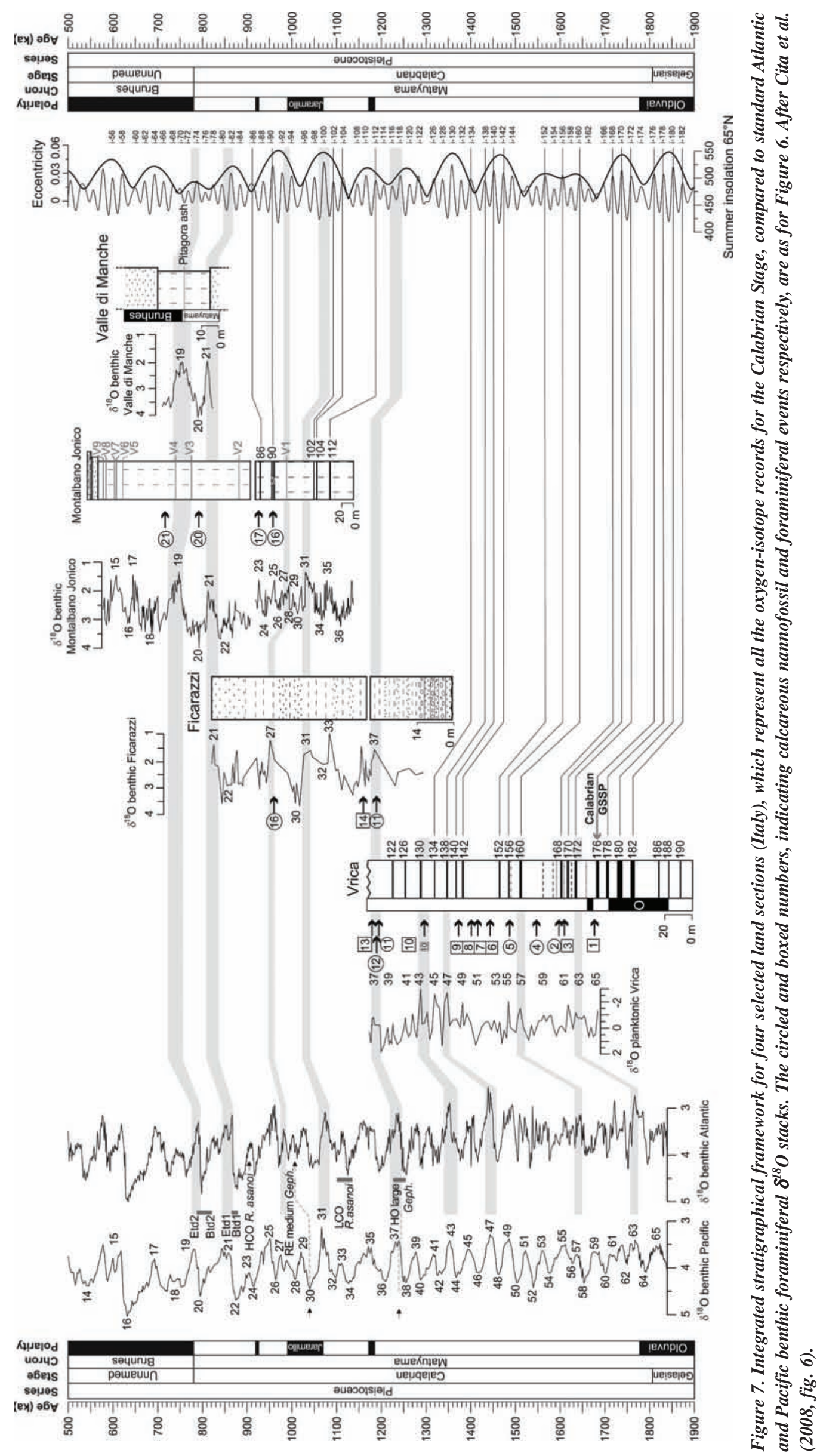


proposal (Selli et al., 1977) and formal approval (Aguirre and Pasini, 1985), as for example: Tauxe et al. (1983), Backman et al. (1983), Combourieu-Nebout (1987), Howell et al. (1990), Hilgen (1990), and Zijderveld et al. (1991).

Only biostratigraphic markers provide a unidirectional, nonrepetitive succession of events. Those at Vrica include the following calcareous nannofossil events: highest occurrence (HO) of Discoaster brouweri at $c .70 \mathrm{~m}(=c .210 \mathrm{kyr})$ below the GSSP, and lowest occurrence (LO) of medium-sized Gephyrocapsa (including $G$. oceanica) at $c .26 \mathrm{~m}$ (c. $78 \mathrm{kyr}$ ) above the GSSP; and the following planktonic foraminiferal events: lowest common occurrence of leftcoiling Neogloboquadrina pachyderma at $c .3 \mathrm{~m} \mathrm{(=c.} 9 \mathrm{kyr}$ ) above the GSSP, and LO of Globigerinoides tenellus at $c .28 \mathrm{~m}$ (=c.84 kyr) above the GSSP. The durations in parentheses assume an average sedimentation rate of $1 \mathrm{~m}$ per 3000 years (Fig. 6). Of these events, the $\mathrm{HO}$ of Discoaster brouweri seems to have the greatest potential for global correlation, with an age of $2.06 \mathrm{Ma}$ in the eastern equatorial Pacific, and 1.93 Ma in the western equatorial Atlantic (Lourens et al., 2005a). Cita et al. (2008) provided a detailed biostratigraphic evaluation of the Vrica section.

\section{Global correlation potential of the Calabrian Stage GSSP}

The Vrica section has been investigated in recent years using isotope, sapropel, and pollen stratigraphies to construct a detailed astrocyclostratigraphy (Lourens et al., 1996, 1998; Suc et al., 2010), and this has created the potential for high-resolution global correlation alongside the previously-mentioned magnetostratigraphical and biochronological criteria. Indeed, the Crotone Series, which includes the Vrica section, is without doubt the best-studied Lower Pleistocene succession in the world, and has been the subject of a recent synthesis (Suc et al., 2010).

The base Calabrian GSSP occurs at the Marine Isotope Stage (MIS) 65/64 transition in the Quaternary marine isotope stratigraphy. Sapropel 'e', as originally identified in segment B of the Vrica section (Fig. 4), corresponds to layer 176 of the Mediterranean PrecessionRelated Sapropels (MPRS) in the calibrated scale of Lourens (2004). This is the highest temporal resolution available at this time, and is corroborated by the robust framework derived by other stratigraphical subdisciplines (Figs. 6, 7).

An age of $1.80 \mathrm{Ma}$ is here assigned to the Vrica GSSP based on comparison with a detailed study of sapropel 'c', which is just below sapropel 'e' at Vrica. Sapropel 'c' has a duration of 9,180 years, beginning with a 2,300-year delay with respect to increased runoff directly correlated to precession, and ending $c$. 700 years after the decrease in runoff (Suc et al. 2010). The asymmetrical development of this sapropel results in a midpoint that is a little less than 2000 years younger than the precession minimum (Suc et al. 2010, fig. 8). Assuming sapropel 'e' at Vrica to be broadly similar, and given that its midpoint has been assigned an age of $1.806 \mathrm{Ma}$ based on orbital tuning which includes an estimated 3000-year time lag between maximum insolation and sapropel midpoint (Lourens et al., 1996, 2005b), the age of the Vrica GSSP at the base of the overlying claystone can then be derived. Hence, by assuming a duration of $c$. 9000 years for sapropel 'e' and a time lag of c. 2000 (rather than 3000 ) years between its midpoint and peak insolation at $1.809 \mathrm{Ma}$, the Vrica GSSP has an age of $c .1 .8025 \mathrm{Ma}$, assuming that the complete sapropel has been preserved. In rounding this figure to $1.80 \mathrm{Ma}$, allowance is made for small errors in orbital tuning and uncertainty in the precise duration of sapropel 'e' deposition. A similar approach was used to date the Monte San Nicola GSSP, which defines the base of the Quaternary (Gibbard and Head, 2009).

To summarise, the marl bed that defines the GSSP at its base may be correlated beyond Vrica by a combination of lithostratigraphy, cyclostratigraphy, and stable isotope analysis; broadly guided by magnetostratigraphy and biostratigraphy. Sapropel stratigraphy offers excellent potential for correlating this marl bed within the eastern Mediterranean basin, although it cannot be used for correlation beyond the Mediterranean.

No major cooling event is recorded at or near the GSSP level, where short-duration precessional cycles prevail in the Mediterranean domain, as well as in the world's oceans.

\section{Acknowledgements}

We are most grateful to Jim Ogg (Purdue University) for discussions, and Jim Ogg and Stan Finney (California State University, Long Beach) for their constructive reviews of the manuscript. Mike Lozon (Brock University) provided assistance with drafting. Luca Capraro (University of Padova) is thanked for providing photos and scale for Segment B of the Vrica section.

\section{References}

Aguirre, E., and Pasini, G., 1985. The Pliocene-Pleistocene boundary: Episodes, v. 8, pp. 116-120.

Backman, J., Shackleton, N.J., and Tauxe, L., 1983. Quantitative nannofossil correlation to open ocean deep-sea sections from Plio-Pleistocene boundary at Vrica, Italy: Nature, v. 304, pp. 156-158.

Barbieri, M, Castorina, F., Colalongo, M.L., Pasini, G., and Vaiani, S.C., 1998. Worldwide correlation of the Pliocene/Pleistocene GSSP at Vrica (Southern Italy) confirmed by strontium isotope stratigraphy: Newsletters on Stratigraphy, v. 36, pp. 177-187.

Capraro, L., Asioli, A., Backman, J., Bertoldi, R., Channell, J.E.T., Massari, F., and Rio, D., 2005. Climatic patterns revealed by pollen and oxygen isotope records across the Matuyama-Brunhes boundary in the central Mediterranean (southern Italy). In: Head, M.J. and Gibbard, P.L. (eds.), 2005. Early-Middle Pleistocene transitions: the land-ocean evidence. Geological Society of London, Special Publications, v. 247, pp. 159182.

Channell, J.E.T., Di Stefano, E., and Sprovieri, R., 1992. Calcareous plankton biostratigraphy, magnetostratigraphy and paleoclimatic history of the Plio-Pleistocene Monte S. Nicola section (Southern Sicily): Bollettino della Società Paleontologica Italiana, v. 31, pp. 351-382.

Ciaranfi, N., D’Alessandro, A., Girone, A., Maiorano, P., Marino, M., Soldani, D., and Stefanelli, S., 2001. The Pleistocene sections in the Montalbano Jonico area and the potential GSSP for Early-Middle Pleistocene in the Lucania Basin (Southern Italy). In: Ciaranfi, N., Pasini, G., and Rio, D. (eds.), The meeting on the Plio/Pleistocene boundary and the Lower/ Middle Pleistocene transition: type areas and sections (Bari, 25-29 September 2000). Memorie di Scienze geologiche di Padova, v. 53, pp. $67-83$

Cita, M.B., 1975. Planktonic foraminiferal biozonation of the Mediterranean Pliocene deep sea record. A revision: Rivista Italiana di Paleontologia e Stratigrafia, v. 81. pp. 527-544.

Cita, M.B., Capraro, L., Ciaranfi, N., Di Stefano, E., Marino, M., Rio, D., Sprovieri, R., and Vai, G.B., 2006. Calabrian and Ionian: A proposal for the definition of Mediterranean stages for the Lower and Middle 
Pleistocene: Episodes, v. 29, pp. 107-114

Cita, M.B., Capraro, L., Ciaranfi, N., Di Stefano, E., Lirer F., Maiorano, P., Marino, M., Raffi I., Rio, D., Sprovieri, R., Stefanelli, S., and Vai, G.B., 2008. The Calabrian Stage redefined: Episodes, v. 31, pp. 408-419.

Combourieu-Nebout, N., 1987. Les premiers cycles glaciare-interglaciare en région méditerranéenne d'après l'analyse palynologique de la série plio-pléistocène de Crotone (Italie méridionale). PhD Thesis, Université Montpellier 2, $161 \mathrm{pp}$.

Di Stefano, E., and Rio, D., 1981. Biostratigrafia a nannofossili e biocronologia del Siciliano nella località tipo di Ficarazzi (Palermo-Sicilia): Acta Naturalia de l'Ateneo Parmense, v. 17, pp. 97-111.

Di Stefano, E., Sprovieri, R., and Caruso, A., 1993. High resolution biochronology in the Monte Narbone Formation of the Capo Rossello section and the Mediterranean first occurrence of Globorotalia truncatulinoides: Rivista Italiana di Paleontologia e Stratigrafia, v. 99, pp. 357-369.

Emeis, K.-C., Sakamoto, T., Wehausen, R., and Brumsack, H.-J., 2000. The sapropel record of the eastern Mediterranean Sea - results of Ocean Drilling Program Leg 160: Palaeogeography, Palaeoclimatology, Palaeoecology, v. 158, pp. 371-395.

Gibbard, P.L., and Head, M.J., 2009. IUGS ratification of the Quaternary System/Period and the Pleistocene Series/Epoch with a base at 2.58 Ma: Quaternaire, v. 20, pp. 411-412.

Gibbard, P.L., and Head, M.J., 2010. The newly-ratified definition of the Quaternary System/Period and redefinition of the Pleistocene Series/Epoch, and comparison of proposals advanced prior to formal ratification: Episodes, v. 33 , pp. $152-158$.

Gibbard, P.L., Head, M.J., Walker, M.J.C. and The Subcommission on Quaternary Stratigraphy, 2010. Formal ratification of the Quaternary System/Period and the Pleistocene Series/Epoch with a base at $2.58 \mathrm{Ma}$ : Journal of Quaternary Science, v. 25, pp. 96-102.

Gignoux, M., 1910. Sur la classification du Pliocène et du Quaternaire dans l'Italie du Sud: Comptes rendus hebdomadaires des séances de l'Académie des Sciences, v. 150, pp. 841-844.

Gignoux, M., 1913. Les formations marines pliocènes et quaternaires de l'Italie du Sud et de la Sicilie: Annales de l'Université de Lyon, n.s. 1, fasc. 36, pp. 1-693.

Head, M.J., Gibbard, P.L., and Salvador, A., 2008a. The Quaternary: its character and definition: Episodes, v. 31, pp. 234-238.

Head, M.J., Pillans, B., and Farquhar, S., 2008b. The Early-Middle Pleistocene Transition: characterization and proposed guide for the defining boundary: Episodes, v. 31, p. 255-259.

Hedberg, D.H., 1976. International Stratigraphic Guide - A guide to stratigraphic classification, terminology and procedure: John Wiley and Sons, New York, p. 1-200.

Hilgen, F.J., 1990. Closing the gap in the Plio-Pleistocene boundary stratotype sequence of Crotone (southern Italy). Newsletters on Stratigraphy, v. 32, pp. 43-51.

Howell, M.H., Rio, D., and Thunell, R., 1990. Laminated sediments from the Vrica section (Calabria, southern Italy): evidence for Plio-Pleistocene warming and cooling trends in the Mediterranean region: Palaeogeography, Palaeoclimatology, Palaeoecology, v. 78, pp. 195-216.

Kroon, D., Alexander, I., Little, M., Lourens, L.J., Matthewson, A., Robertson, A.H.F., and Sakamoto, T., 1998. Oxygen isotope and sapropel stratigraphy in the eastern Mediterranean during the last 3.2 million years. In: Robertson, A.H.F., Emeis, K.-C., Richter, C., and Camerlenghi, A. (eds.), Proceedings of the Ocean Drilling Program, Scientific Results, v. 160, pp. 181-190.

Lourens, L.J., 2004. Revised tuning of Ocean Drilling Program Site 964 and KC01B (Mediterranean) and implications for the $\delta^{18} \mathrm{O}$, tephra, calcareous nannofossil, and geomagnetic reversal chronologies of the past 1.1 Myr: Paleoceanography, v. 19, PA3010.

Lourens, L.J., Hilgen, F.J., and Raffi, I., 1998. Base of large Gephyrocapsa and astronomical calibration of early Pleistocene sapropels in Site 967 and Hole 969D: solving the chronology of the Vrica section (Calabria, Italy). In: Robertson, A.H.F., Emeis, K.-C., Richter, C., and Camerlenghi,
A. (eds.), Proceedings of the Ocean Drilling Program, Scientific Results, v. 160 , pp. $191-197$

Lourens, L.J., Hilgen, F.J., Raffi, I., and Vergnaud-Grazzini, C., 1996. Early Pleistocene chronology of the Vrica section (Calabria, Italy): Paleoceanography, v. 11 , no. 6, p. 797-812.

Lourens, L.J., Hilgen, F.J., Shackleton, N.J., Laskar, J., and Wilson, D., 2005a. Appendix 2. Orbital tuning calibrations and conversions for the Neogene Period. In: Gradstein, F., Ogg, J., and Smith, A. (eds.), A geologic time scale 2004: Cambridge University Press, Cambridge, U.K., pp. 469484. [Imprinted 2004]

Lourens, L.J., Hilgen, F.J., Shackleton, N.J., Laskar, J., and Wilson, D., 2005b. The Neogene Period. In: Gradstein, F., Ogg, J., and Smith, A. (eds.), A geologic time scale 2004: Cambridge University Press, Cambridge, U.K., pp. 469-484. [Imprinted 2004]

Maiorano, P., Capotondi, L., Ciaranfi, N., Girone, A., Lirer, F., Marino, M., Pelosi, N., Petrosino, P., and Piscitelli, A., 2010. Vrica-Crotone and Montalbano Jonico sections: A potential unit-stratotype of the Calabrian Stage: Episodes, v. 33, pp. 218-233.

Martini, E., 1971. Standard Tertiary and Quaternary calcareous nannoplankton zonation: Proceedings II Planktonic Conference, Roma, 1970, v. 2, pp. $738-785$.

Massari, F., Rio, D., Sgavetti, M., Prosser, G., D'Alessandro, A., Asioli, A., Capraro, L., Fornaciari, E., and Tateo, F., 2002. Interplay between tectonics and glacio-eustasy: Pleistocene of the Crotone Basin, Calabria (southern Italy): Geological Society of America Bulletin, v. 114, pp. 1183-1209.

Murat, A., 1999. Pliocene-Pleistocene occurrence of sapropels in the western Mediterranean Sea and their relation to eastern Mediterranean sapropels. In: Zahn, R., Comas, M.C., and Klaus, A. (eds.), Proceedings of the Ocean Drilling Program, Scientific Results, v. 161, pp. 519-528.

Nakagawa, H., Niitsuma, N., Takayama, T., Matoba, Y., Oda, M., Tokunaga, S., Kitazato, H., Sakai, T., and Koizumi, I., 1997. The magnetostratigraphy of the Vrica section, Italy, and its correlation with the Plio-Pleistocene of the Boso Peninsula, Japan. In: Van Couvering, J. (ed.), The Pleistocene boundary and the beginning of the Quaternary: Cambridge University Press, Cambridge, U.K., pp. 46-56.

Okada, H., and Bukry, D., 1980. Supplementary modification and introduction of code numbers to the low-latitude coccolith biostratigraphic zonation: Marine Micropaleontology, v. 5, pp. 321-325.

Pasini, G., and Colalongo, M.L., 1997. The Pliocene-Pleistocene boundarystratotype at Vrica, Italy. In: Van Couvering, J. (ed.), The Pleistocene boundary and the beginning of the Quaternary: Cambridge University Press, Cambridge, U.K., pp. 15-45.

Rio, D., Raffi, I., and Villa, G., 1990. Pliocene-Pleistocene calcareous nannofossil distribution patterns in the Western Mediterranean. In: Kastens, K.A., Mascle, J., et al. (eds.), Proceedings of the Ocean Drilling Program, Scientific Results, v. 107, pp. 513-532.

Rio, D., Sprovieri, R., Castradori, D., and Di Stefano, E., 1998. The Gelasian Stage (Upper Pliocene): A new unit of the global standard chronostratigraphic scale: Episodes, v. 91, pp. 82-87.

Roberts, A.P., Florindo, F., Larrasoaña, J.C., O'Regan, M.A., and Xiang Zhao, 2010. Complex polarity pattern at the former Plio-Pleistocene global stratotype section at Vrica (Italy): Remagnetization by magnetic iron sulphides: Earth and Planetary Science Letters, v. 292, pp. 98-111.

Selli, R., Accorsi, C.A., Bandini Mazzanti, M., Bertolani Marchetti, D., Bigazzi, G., Bonadonna, F.P., Borsetti, A.M., Cati, F., Colalongo, M.L., D’Onofrio, S., Landini, W., Menesini, E., Mezzetti, R., Pasini, G., Savelli, C., and Tampieri, R., 1977. The Vrica section (Calabria-Italy). A potential Neogene-Quaternary boundary stratotype: Giornale di Geologia, v. 41, pp. 181-204.

Sprovieri, R., 1993. Pliocene-Early Pleistocene astronomically forced planktonic foraminifera abundance fluctuations and chronology of Mediterranean calcareous plankton bio-events: Rivista Italaliana di Paleontologia e Stratigrafia, v. 99, no. 3, pp. 371-414.

Suc, J.-P., Combourieu-Nebout, N., Seret, G., Popescu, S.-M., Klotz, S., Gautier, F., Clauzon, G., Westgate, J., Insinga, D., and Sandhu, A.S., 
2010. The Crotone series: A synthesis and new data. Quaternary International, v. 219, pp. 121-133.

Tauxe, L., Opdyke, N.D., Pasini, G., and Elmi, C., 1983. Age of the PlioPleistocene boundary in the Vrica section, southern Italy: Nature, v. 304, pp. $125-129$.

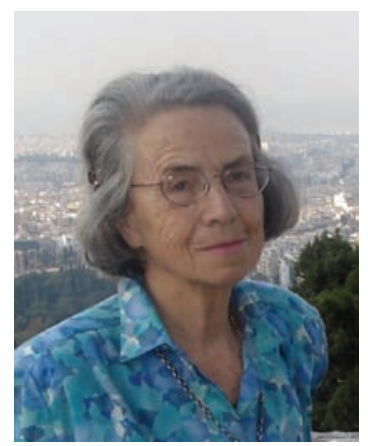

Maria Bianca Cita is an Emeritus Professor of Geology at the University of Milan, Italy. An expert in marine geology and the Mediterranean Neogene, she served several times as shipboard scientist in the early days of the Deep Sea Drilling Project (Legs 2, 13, 40, 47) and was Project Leader of IGCP Project 96 'Messinian Correlation' (key-Project, 1975-79). She is a former chair of the Italian Commission on Stratigraphy, the International Commission on Stratigraphy's Subcommission on Stratigraphic Classification, the ICS Subcommission on Neogene Stratigraphy, the Geological Society of Italy, AIQUA, and ESCO (Science Committee of the European Consortium of Ocean Research Drilling).

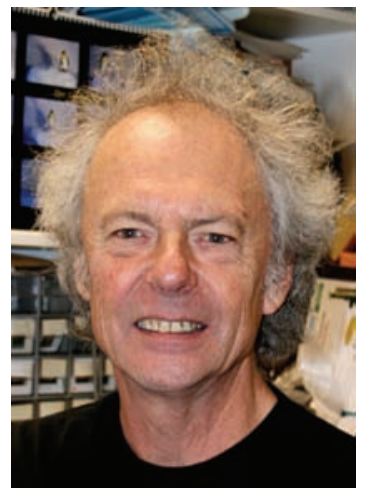

Phil Gibbard is Professor of Quaternary Palaeoenvironments at the University of Cambridge, United Kingdom, and Past-Chair of the International Commission on Stratigraphy's Subcommission on Quaternary Stratigraphy. He is currently President, and was formerly Secretary, of the Stratigraphy and Chronology Commission of INQUA, and is a member of the INQUA Subcommission of European Quaternary Stratigraphy, and the Geological Society of London's Stratigraphy Commission. His research is focused on terrestrial and shallow marine sedimentation, stratigraphy and environmental evolution throughout Europe, but he has also worked in the Arctic, North America, Turkey, India and South-East Asia.
Zijderveld, J.D.A, Hilgen, F.J., Langereis, C.G., Verhallen, P.J.J.M., and Zachariasse, W.J., 1991. Integrated magnetostratigraphy and biostratigraphy of the Upper Pliocene-Lower Pleistocene from the Monte Singa and Crotone areas in Calabria (Italy): Earth and Planetary Science Letters, v. 107, pp. 697-714.

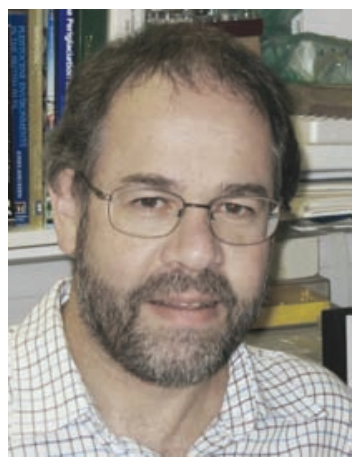

Martin J. Head is a Professor of Earth Sciences at Brock University. He was previously at the University of Cambridge, and before that spent 14 years at the University of Toronto where he maintains an affiliation. He is Chair of the International Commission on Stratigraphy's Sub-commission on Quaternary Stratigraphy, and is CoConvener of its Working Group on the Lower-Middle Pleistocene Boundary. He is Chair of the Canadian Stratigraphy Commission, and a member of the INQUA Stratigraphy and Chronology Commission. His interests include Cenozoic stratigraphy and marine palynology, and particularly the late Cenozoic record of dinoflagellate cysts and acritarchs. Martin holds a PhD from the University of Aberdeen. 